\title{
Coppice Forest Management Planning and the Regene- ration Potential of Pure and Mixed Oak Coppice Forests in North Macedonia
}

\author{
Pande Trajkov ${ }^{1 *}$, Tomislav Dubravac ${ }^{2}$, Vladimir Tanovski ${ }^{1}$, Ljupco Nestorovski ${ }^{1}$, Kiril Sotirovski ${ }^{1}$, \\ Zdravko Trajanov ${ }^{1}$
}

(1) "Ss. Cyril and Methodius" University, Faculty of Forestry, Aleksandar Makedonski bb, MK1000 Skopje, Republic of North Macedonia; (2) Croatian Forest Research Institute, Division for Silviculture, Cvjetno naselje 41, HR-10450 Jastrebarsko, Croatia

* Correspondence: e-mail: pbabunski@gmail.com

\begin{abstract}
Citation: TRAJKOV P, DUBRAVAC T, TANOVSKI V, NESTOROVSKI LJ, SOTIROVSKI K, TRAJANOV Z 2019 Coppice Forest Manage-ment Planning and the Regeneration Potential of Pure and Mixed Oak Coppice Forests in North Macedonia. South-east Eur for 10 (2): 165-172. DOI: https://doi.org/10.15177/seefor.19-20 Received: 21 Jun 2019; Revised: 28 Sep 2019; Accepted: 4 Oct 2019; Published online: 3 Nov 2019
\end{abstract}

\begin{abstract}
Background and Purpose: Coppicing is the most widely used silvicultural system in North Macedonia and coppice forests together with shrubs cover cca. $69 \%$ of the forest cover area. Pure and mixed stands of oak coppice forests alone cover about $50 \%$ of the total forest area subject to current Forest Management Plans. In general, coppices are routinely managed, especially when coppicing as a system is planned to be continued. However, sustainability can be threatened if attention is not paid regarding the age of trees/stands and the presence of undesired tree species. The purpose of this study was to determine: (1) quantitative and qualitative aspects of planned management activities in oak coppices throughout the country, (2) the resprouting potential of over-mature oak coppices, and (3) their potential for generative regeneration.

Materials and Methods: We analyzed all official forest management plans in the country, in order to assess planned activities and the methods of management. Additionally, 21 experimental plots were set in order to determine the resprouting potential of over-mature (85 to 95 years) coppices of Quercus petraea and $Q$. frainneto which previously have been subject of clear-cutting. We took a total count of sprouts on all experimental plots, while generative regeneration seedlings were counted on 4 schematically positioned subplots in each experimental plot. Sprouts and generative seedlings were categorized by height.

Results and Conclusions: According to the data from forest management plans, coppicing is planned to remain as a management system on 401,636 ha, of the total of 450,975 ha of oak coppice forests. Indirect conversion to high forests is planned on 39,137 ha, while direct conversion with substitution is planned for 10,202 ha. In field trials, resprouting was registered on only $38 \%$ of the stools. Generative regeneration was recorded in both oak species in numbers which indicate good potential for conversion of oak coppice stands into high forests by seed felling. However, numerous sprouts of other species (Corylus avellana, Fraxinus ornus, Acer heldreichii), which reach up to 3 meters in height within two seasons, are potentially dangerous for dominating oak seedlings.
\end{abstract}

Keywords: management activities, resprouting, vegetative regeneration, generative regeneration

\section{INTRODUCTION}

Coppicing has been, and in many cases still is, an important traditional forest land use system across Europe [1]. Apart from providing many wood products, such as firewood, biomass chips, fencing, assorted and industrial wood, coppice forests are a source for a variety of non-wood forest products, such as truffles, mushrooms and honey [2].

While in Central and Northern Europe coppice forests comprise just a small share of the total forest area (e.g. in Austria $2 \%$; Germany $0.7 \%$ ), they take up a large part of the forest area in South-Eastern Europe (e.g. Croatia 21\%, 
Albania 43\%, Bulgaria and France 47\%, North Macedonia 59\% (without shrubs), Serbia and Greece 65\% each) [3$6]$. Both high diversity of site conditions and vegetation patterns in South-Eastern Europe, accompanied by diverse socio-cultural backgrounds of countries, have induced an abundance of diverse coppice stands and a variety of management practices [5].

In historical regards, the most important common characteristics in the establishment of coppicing as a practice were the absence of any silvicultural activities in the early ages and very weak and inadequate silvicultural treatments in the later stages $[5,7,8]$.

Coppicing as a practice has been and still is usually performed by the method of annual coupes by area, and regeneration is achieved by stool shoots or suckers. In most tree species, stools of large sizes do not coppice strongly, hence for the production of stool shoots it is usually necessary to fell trees at an age of not above than 40 years [9]. The rotation usually varies from 10 to 30 , or even up to 40 years, depending on the region, tree species and market demands $[3,10]$.

In North Macedonia (at the time People's Republic of Macedonia) after World War II, coppice forests occupied 648,000 ha, which was cca. $75 \%$ of the total forest covered area. Of these, 286,000 ha were regular coppice forests, 131,000 ha were overused forests and 231,000 ha were shrubs [11]. In the second half of the $20^{\text {th }}$ century, as a result of the fast development of the wood industry and of the fear of deficiency of technical wood, the attention of both researchers and practitioners was focused on the transformation of coppice forests into high forests [11-19]. One of the results of their efforts is the "Long-term Program for development of forestry in SR Macedonia for the period 1971-1990". Within this Program coppice forests are classified into regular coppice forests, occupying 250,700 ha, and degraded coppice forests, occupying 379,000 ha, of which shrubs occupy 155,500 ha and pollarded and shredded forests 27,200 ha.

Within this Program, regular coppice forests are classified into three categories: i) coppice forests which will continue to be managed as such, ii) coppice forests on rich sites, planned for conversion into high forests by the method of indirect conversion, and iii) coppice forests planned for direct conversion by the method of substitution of tree species.

Degraded coppice forests are further classified as degraded and highly degraded, and for them resurrective cutting and direct conversion are planned, respectively.

For the period of validity of the Program, indirect conversion was planned for all categories and tree species of coppice forests on an area of 150,000 ha, in two time points, set apart by 10 (8-12) years, while direct conversion was planned for an area of 92,000 ha.

During the $20^{\text {th }}$ century, a strategic concept related to coppice forests in Europe was their transformation into high forests, and in some countries this concept continues at present $[6,21]$. Their transformation is managed by means of direct and indirect conversion. It should be noted here that there is ambiguity regarding the definition of the terms direct and indirect conversion, especially in
European academic literature. In some Balkan countries (especially ex-Yugoslavia), the term indirect conversion refers to the transformation of coppice forest stands with a sufficient number of good quality trees, evenly distributed throughout the stand, which will provide seeding and conversion of coppices into high forests by natural means $[8,22]$. This same procedure of transformation of coppice forests into high forest stands is defined by some authors as direct conversion: "The method of direct conversion includes (i) conversion by ageing.... where the simple coppice is no longer cut so that stands reach a maturity in which they are able to regenerate naturally by seed" [23]. In this paper, the meaning of terms (direct and indirect conversion) is according to the definitions used in Balkan countries (in particular ex-Yugoslavia).

The total forest covered area in North Macedonia in 2017 was 1,001,489 ha (Statistical Yearbook 2018). Forest management planning in the country is realized through FMPs, FMPr and by instructions for management of smallscale private forests (Forest Law 2009).

However, even 30 years after the expiration of the Program, no analyses were derived from the extent, quality and success of the undertaken activities. This fact was our main motive to collect and analyze data from the current FMPs for the planned means, methods and activities in coppice oak forests, as well as to analyze results in situ within areas managed as coppices. Our main task was to generate data which would clarify the regenerative potential of over-aged coppice oak forests, and eventually shed light on the capacity for vegetative or generative regeneration.

\section{MATERIAL AND METHODS}

\section{Planned Management Activities}

Planning and management of forests in North Macedonia is based on Forest Management Plans (FMPs) which are made for areas larger of $30 \mathrm{ha}$, and Forest Management Programs (FMPr) for forests between 10 and 30 ha. Forests up to 10 ha are managed by instructions issued by the Ministry of Agriculture, Forestry and Water Economy of RNM for managing small scale private forests (Forest Law, 2009).

In the process of forest management planning, the level at which sustainability is provided (guaranteed), i.e. wood production or yield sustainability, is the management class (MC), which is defined as a sum of areas of stands which will be managed in the same manner in the future. The MCs are defined with the Rulebook for the content of FMP. Depending on site and stand quality, some MCs are further divided into subclasses.

Accordingly, coppice oak forests are grouped into 2 MCs - coppice $Q$. petraea forests designated as MC ' $M$ ' and coppice forests of other oak species ( $Q$. conferta, $Q$. cerris, $Q$. macedonica, $Q$. pubescens) designated as $M C$ executive class ' $L$ '. Depending on the site and stand quality, coppice $Q$. petraea forests (class ' $\mathrm{M}$ ') are further divided into 4 subclasses (M1-M4).

In order to assess the planned activities and the methods of management, we analyzed all 197 official forest 
management plans in the country. Planned activities were grouped by MCs (subclasses) and the type of activity.

\section{Regeneration Potential}

We set 21 circular experimental plots (EPs) in order to determine the regeneration potential of over-mature oak coppice stands, in which clear-cut has been previously performed. We located the EPs in 2 locations in North Macedonia. One was in the western part of the country near the city of Kichevo, on over-mature $Q$. petraea coppice forest stands (QPCF) in the management unit (MU) "Ljuben - Srbjani", while the other was in the eastern part of the country near the city of Berovo, on over-mature Quercus frainetto coppice forest (QFCF) stands in MU "Goten - Shiroki Dol".

EPs each had a radius of 5.64 meters, i.e. an area of 100 $\mathrm{m}^{2}$, and were grouped into clusters of three, whereof they were positioned on the vertices of an equilateral triangle with side length of 50 meters (Figure 1). Clusters were randomly located in each stand.

During 2015 and 2017, a count was made of all sprouting and dead stools in each EP. On each sprouting stool all sprouts were counted and categorized in 6 classes based on height (up to $30 \mathrm{~cm}$; $31-60 \mathrm{~cm} ; 61-130 \mathrm{~cm} ; 131-200 \mathrm{~cm} ; 201-250 \mathrm{~cm}$, and $251-300 \mathrm{~cm}$ ).

Four subplots with a radius of $1 \mathrm{~m}$ were set in each EP; the first subplot was positioned in the center of the EP, while the remaining 3 subplots were positioned at a distance of $3 \mathrm{~m}$ in relation to the center of the first one, at azimuths of $120^{\circ}$, $240^{\circ}$ and $360^{\circ}$. In each subplot, all individuals of generative origin were counted, and their heights were registered. Individuals were categorized in the same 6 classes based on height, as described previously for the sprouts.

At MU "Ljuben-Srbjani" in QPCF stands, a total of 12 EPs were set in four clusters, i.e. two clusters in each of the departments $4 \mathrm{a}$ and $61 \mathrm{a}$. According to the FMP, in department 4a a clear-cut was performed two vegetation periods prior to our assessments. At the time of cutting, the stand was aged
85 years, mean diameter of breast height $\left(d_{\mathrm{g}}\right)$ was $18 \mathrm{~cm}$, mean height $\left(h_{g}\right) 16 \mathrm{~m}$, and there were 532 trees per hectare. In department 61 a, a clear-cut was performed one vegetation period prior to our assessments when the stand was aged 87, mean diameter of breast height $\left(\mathrm{d}_{\mathrm{g}}\right)$ was $22 \mathrm{~cm}$, mean height $\left(h_{g}\right) 17 \mathrm{~m}$, and there were 706 trees per hectare.

At MU "Goten-Shiroki Dol" in QFCF stands, a total of 9 experimental plots were set in three clusters, of which two clusters in department $5 \mathrm{a}$ and one cluster in department 54a. At department $5 \mathrm{a}$ a clear-cut was performed five vegetation years prior to our assessments when the stand was aged 95 years $\left(d_{1,3}=23 \mathrm{~cm}, \mathrm{~h}_{\mathrm{sr}}=17 \mathrm{~m}, \mathrm{~N}=532\right)$. At department $54 \mathrm{a}$, a clear-cut was performed one vegetation year prior to our assessments when the stand was aged 92 years $\left(d_{1,3}=22 \mathrm{~cm}\right.$, $\mathrm{h}_{\mathrm{sr}}=15 \mathrm{~m}, \mathrm{~N}=747$ ).

\section{RESULTS}

\section{Planned Activities}

According to our analyses, the total forest cover area which is subject to current FMPs for the entire country is 888,649 ha (state 2017). Of these, Q. petraea coppice forests (QPCF) are classified as management class ' $\mathrm{M}$ ' and cover an area of 163,036 ha. For QPCF, at the class level, simple coppicing (coppice system \& resurrection) is planned to continue on an area of 114,447 ha. On the other hand, the transformation of coppice stands to high forests is planned for 16,409 ha through indirect conversion, while for 3,749 ha through direct conversion with substitution. For 28,432 ha QPCF objectives are not defined, and the often-used term in these cases is "stands at rest" (Table 1). This term is usually applied for low productive oak coppice stands or small areas at the management class level which have been recently coppiced. For those types of stands even the aim of management is not defined, and they are just categorized as management class/subclass in a specific Forest Management Unit (FMU).

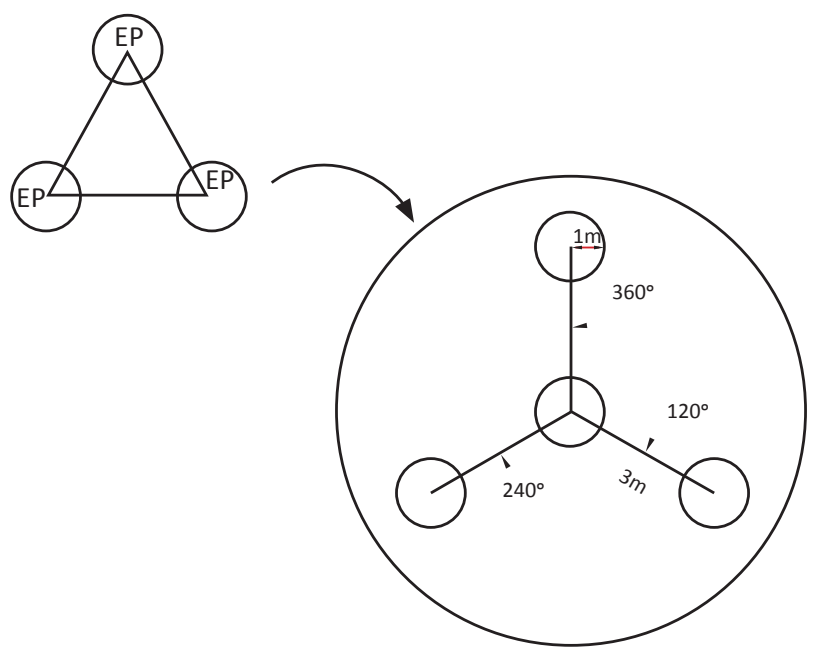

FIGURE 1. Cluster of the experimental plots. 


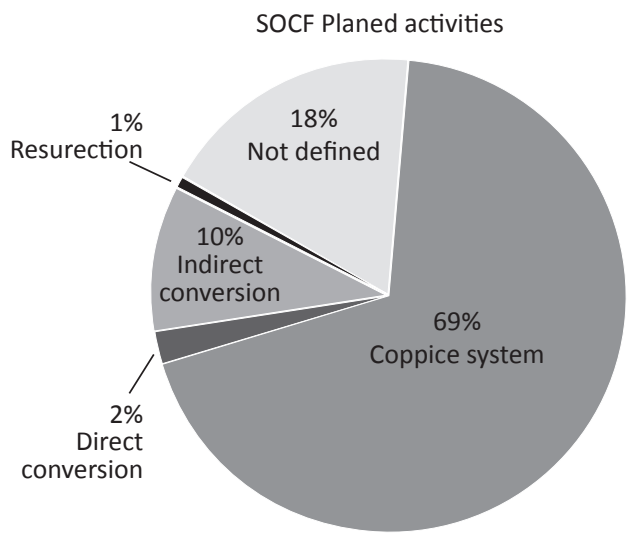

FIGURE 2. Planned activities in sessile oak coppice forest (\%).

According to site and stand quality, QPCF are divided into four stand types: i) quality QPCS on quality sites management subclass 'M1'; ii) low-quality QPCS on good quality (rich) sites - management subclass 'M2'; iii) lowquality QPCS on poor sites - management subclass 'M3'; and iv) QPCS in which other species are introduced, deciduous or coniferous - management subclass 'M4'.

Stands of the management subclass ' $M 1$ ' cover an area of 39,306 ha. Of these, 15,470 ha are planned to be managed as coppice forests in the future; for 15,051 ha transformation into high forests is planned through indirect conversion, while no activities are planned for 8,785 ha.

Stands of the management subclass ' $\mathrm{M} 2$ ' cover an area of 112,179 ha. The majority of these stands, 92,960 ha, are set to continue to be managed as coppice forests. For 1,358 ha transformation into high forests is planned through indirect conversion; 3,609 ha are planned to be transformed into high forests through direct conversion, while for 12,908 ha no activities are planned.

Stands considered as management subclass ' $\mathrm{M} 3$ ' cover an area of 9,442 ha. For about half of those ( 4,832 ha) no activities have been decided; for 4,470 ha it is planned to be managed as coppice forests in the future, while for only 40 ha transformation into high forests is planned through direct conversion.

Stands within management subclass 'M4' cover an area of 2,109 ha. In these stands, various coniferous or broadleaved species have been introduced, by means of planting of seedlings or by sowing seeds, but the main part is still coppice. For stands in this subclass, clear-cutting is planned on a total area of 203 ha.

Other oak species present in the country (Q. frainetto Ten., Q. cerris L., Q. macedonica A.DC., Q. pubescens Willd.) are in a separate management class ' $\mathrm{L}$ ' and cover an area of 287,938 ha. In some FMPs stands are grouped into subclasses, while in others not, because according to the Rulebook for the content of FMPs (1998) the division into subclasses of these stands is not compulsory. Because of this reason, the analyses for stands within ' $L$ ' management classes are performed on the class level only (Table 2).

In this management class, it is planned for nearly $80 \%(79.61 \%)$ of the stands to continue to be managed as coppice forests. Indirect conversion is planned for an area of 22,728 ha $(7.89 \%)$, direct conversion for 6,453 ha, resurrection for 7,466 ha, while for 29,511 ha $(10.25 \%)$ the type of management is not defined (Figure 3 ).

TABLE 1. Planned activities for coppice forests of management class 'M' according to FMPs (state 2017).

\begin{tabular}{|c|c|c|c|c|c|c|}
\hline \multirow{2}{*}{$\begin{array}{l}\text { Type of stands } \\
\text { (subclass) }\end{array}$} & \multirow{2}{*}{$\begin{array}{c}\text { Total area of } \\
\text { subclass }\end{array}$} & \multicolumn{5}{|c|}{ Planned activities in ha } \\
\hline & & Coppice system & Indirect conversion & Direct conversion & Resurrection & Not defined \\
\hline M1 & 39306 & 15470 & 15051 & & & 8785 \\
\hline M2 & 112179 & 92960 & 1358 & 3609 & 1344 & 12908 \\
\hline M3 & 9442 & 4470 & & 140 & & 4832 \\
\hline M4 & 2109 & 203 & & & & 1906 \\
\hline Total M & 163036 & 113103 & 16409 & 3749 & 1344 & 28431 \\
\hline$\%$ & 100 & 69.4 & 10.1 & 2.3 & 0.8 & 17.4 \\
\hline
\end{tabular}

TABLE 2. Planned activities for coppice forests of management class 'L' according to FMPs (state 2017).

\begin{tabular}{|c|c|c|c|c|c|c|}
\hline \multirow{2}{*}{$\begin{array}{l}\text { Management } \\
\text { class 'L' }\end{array}$} & \multirow{2}{*}{$\begin{array}{l}\text { Total area of } \\
\text { subclass }\end{array}$} & \multicolumn{5}{|c|}{ Planned activities in ha } \\
\hline & & Coppice system & Indirect conversion & Direct conversion & Resurrection & Not defined \\
\hline ha & 287.938 & 221.781 & 22.728 & 6.453 & 7.466 & 29.511 \\
\hline$\%$ & 100 & 77.02 & 7.89 & 2.24 & 2.59 & 10.25 \\
\hline
\end{tabular}


Other oak species planed activities

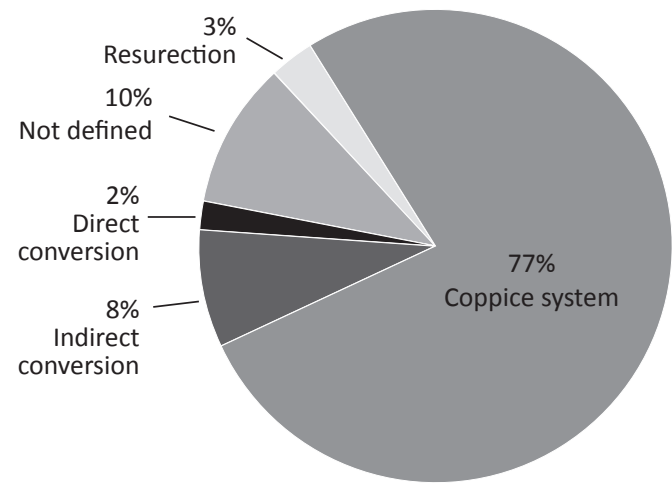

FIGURE 3. Planned activities in coppice forests on other (Q. frainetto, Q. macedonica, Q. pubescens) oak species (\%).

\section{Regeneration Potential}

In department 61a we registered 751 stools per hectare, of which 317 were regenerating and 431 were dead. On the regenerated stools we counted 5,139 sprouts per hectare, of which 1,318 were $30 \mathrm{~cm}$ or less, 2,236 were $31-60 \mathrm{~cm}$, and 1,585 were $61-130 \mathrm{~cm}$. In this stand, 1,035 stools of hazel (C. avellana) were registered per hectare, with a count of 14,083 sprouts, of which the majority $(7,776)$ are within the height class $61-130 \mathrm{~cm}$. We also counted 24,632 individuals per hectare of $Q$. petraea of generative origin, all within the height class of $30 \mathrm{~cm}$ or bellow (Table 3, Figure 4)..

In department 4a we registered 701 stools per hectare, of which 234 were regenerated and 467 were dead. On regenerated stools we counted 3,471 sprouts per hectare, of which 384 are $31-60 \mathrm{~cm} ; 1,552$ are $61-130 \mathrm{~cm} ; 1,135$ are 131$200 \mathrm{~cm} ; 267$ are $201-250 \mathrm{~cm}$, and $133251-300 \mathrm{~cm}$ in height. In this department, 617 stools of hazel were registered per hectare on which there were 12,098 sprouts; more than half of those are over $1.3 \mathrm{~m}$ in height, and 1,185 are over $2.5 \mathrm{~m}$. Also, 27,866 individuals per hectare of $Q$. petraea of generative origin were registered, of which 19,904 are $30 \mathrm{~cm}$ or lower and 7,962 are 31-60 cm (Table 3, Figure 5, 6).
In department 54a we registered 590 stools per hectare, of which 134 were regenerating and 456 were dead. On regenerating stools, we registered a total of 1,648 sprouts. Of these, 423 are $30 \mathrm{~cm}$ or bellow; 717 are $31-60 \mathrm{~cm}$, and 508 are $61-130 \mathrm{~cm}$. In this department, we registered 250 stools of Fraxinus ornus per hectare, on which we registered 1,595 sprouts. Of these, 472 are $30 \mathrm{~cm}$ or less; 874 are $31-60 \mathrm{~cm}$, and 249 are $61-130 \mathrm{~cm}$ in height. In the stand, we registered 45,117 seedlings of $Q$. frainetto of generative origin per hectare. Of these, 35,297 are $30 \mathrm{~cm}$ or bellow, and 9,820 seedlings are $31-60 \mathrm{~cm}$ (Table 4).

In department 5 a we registered 366 stools of $Q$. frainetto per hectare, of which 33 were regenerating and 333 were dead. On regenerating stools, we registered 367 sprouts per hectare; 31 of these were $61-130 \mathrm{~cm} ; 178$ are $131-200 \mathrm{~cm}$; 114 are $201-250 \mathrm{~cm}$; and 44 are $251-300 \mathrm{~cm}$. In the stand, we registered 28,264 seedlings of $Q$. frainetto of generative origin per hectare. Of these, 7,962 are $30 \mathrm{~cm}$ or bellow, 13,004 seedlings are $31-60 \mathrm{~cm}$, and 7,298 are $61-130 \mathrm{~cm}$ height. In this department, we registered 67 stools of Fraxinus ornus per hectare, on which we registered 386 sprouts. Of these, 46 are $61-130 \mathrm{~cm}$; 92 are $131-200 \mathrm{~cm}, 137$ are $201-250 \mathrm{~cm}, 102$ are 251-300 cm, and 10 are more than $300 \mathrm{~cm}$ in height (Table 4).

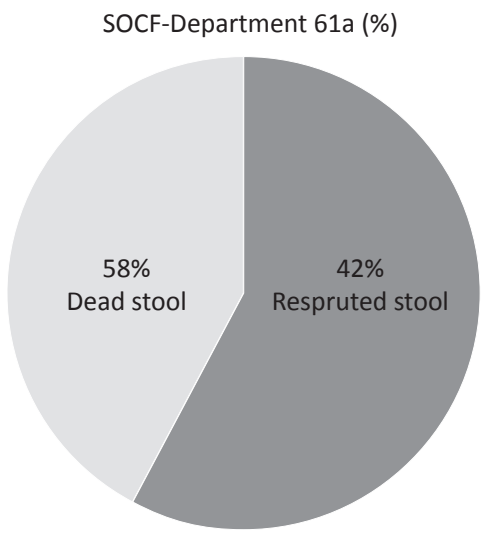

FIGURE 4. Resprouted and dead stools in Q. petraea coppice stands in department 61a.

TABLE 3. The number of stools (resprouted and dead), sprouts and seedlings in QPCF (per hectare).

\begin{tabular}{|c|c|c|c|c|c|c|c|c|c|c|}
\hline \multirow{2}{*}{ Stand } & \multirow{2}{*}{ Species } & \multirow{2}{*}{$\begin{array}{l}\text { Number } \\
\text { of stools / } \\
\text { nests }\end{array}$} & \multicolumn{8}{|c|}{ Number of sprouts - seedlings by height in $\mathrm{cm}$} \\
\hline & & & up to 30 & $31-60$ & $61-130$ & $131-200$ & $201-250$ & $251-300$ & $301-350$ & Total \\
\hline \multirow{4}{*}{$\begin{array}{l}\text { One year } \\
\text { after clear } \\
\text { cut (dprt.61) }\end{array}$} & Oak resprouted & 317 & 1318 & 2236 & 1585 & 0 & 0 & 0 & 0 & 5139 \\
\hline & Oak - dead stool & 434 & & & & & & & & \\
\hline & Hazelnut trees & 1035 & 200 & 6107 & 7776 & 0 & 0 & 0 & 0 & 14083 \\
\hline & Oak & Seedlings & 24632 & 0 & 0 & 0 & 0 & 0 & 0 & 24632 \\
\hline \multirow{4}{*}{$\begin{array}{l}\text { Two years } \\
\text { after clear } \\
\text { cut (dprt.4) }\end{array}$} & Oak resprouted & 234 & 0 & 384 & 1552 & 1135 & 267 & 133 & 0 & 3471 \\
\hline & Oak - dead stool & 467 & & & & & & & & \\
\hline & Hazelnut trees & 617 & 0 & 684 & 3704 & 4272 & 2253 & 1185 & 0 & 12098 \\
\hline & Oak & Seedlings & 19904 & 7962 & 0 & 0 & 0 & 0 & 0 & 27866 \\
\hline
\end{tabular}


TABLE 4. The number of stools (resprouted and dead), sprouts and seedlings in QFCF (per hectare).

\begin{tabular}{|c|c|c|c|c|c|c|c|c|c|c|}
\hline \multirow{2}{*}{ Stand } & \multirow{2}{*}{ Species } & \multirow{2}{*}{$\begin{array}{l}\text { Number } \\
\text { of stools / } \\
\text { nests }\end{array}$} & \multicolumn{8}{|c|}{ Number of sprouts - seedlings by height in $\mathrm{cm}$} \\
\hline & & & up to 30 & $31-60$ & $61-130$ & $131-200$ & 201-250 & 251-300 & $301-350$ & Total \\
\hline \multirow{4}{*}{$\begin{array}{l}\text { One year } \\
\text { after clear cut } \\
\text { (dprt. 54a) }\end{array}$} & Oak resprouted & 134 & 423 & 717 & 508 & & & & & 1648 \\
\hline & Oak - dead stool & 456 & & & & & & & & \\
\hline & Fraxinus ornus & 250 & 472 & 874 & 249 & & & & & 1595 \\
\hline & Oak & Seedlings & 35297 & 9820 & & & & & & 45117 \\
\hline \multirow{4}{*}{$\begin{array}{l}\text { Five years } \\
\text { after clear cut } \\
\text { (dprt. 5a) }\end{array}$} & Oak resprouted & 33 & & & 31 & 178 & 114 & 44 & & 367 \\
\hline & Oak - dead stool & 333 & & & & & & & & \\
\hline & Fraxinus ornus & 67 & & & 46 & 92 & 137 & 102 & 10 & 386 \\
\hline & Oak & Seedlings & 7962 & 13004 & 7298 & & & & & 28264 \\
\hline
\end{tabular}

SOCF-Department $4 a$

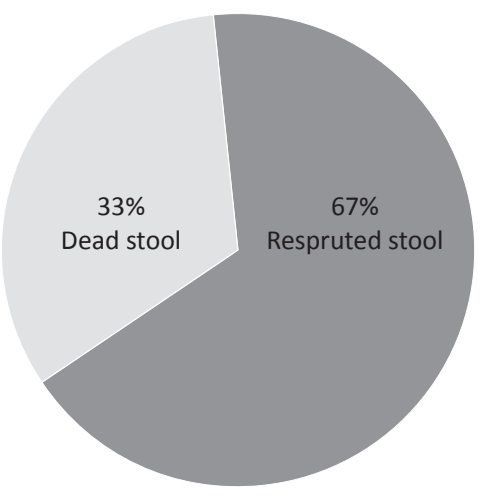

FIGURE 5. Resprouted and dead stools in Q. petraea coppice stands in department $4 a$.

\section{DISCUSSION}

Our research showed that the total area of forests managed by planned and approved FMPs, i.e. managed forests, was 888,649 ha in 2017 , of which 612,479 ha (69\%) are coppice forests and shrubs. The total managed forest coverage has declined from 902,000 ha in 2012 [20]. This registered decrease of the forest areas covered by forest management between 2012 and 2017 is mainly because of a decision in 2014 of the Ministry of Agriculture, Forestry and Water Economy, by which companies managing state-owned forests should exclude private forests from FMPs.

The total area of coppice forests in North Macedonia is 549,267 ha (bushes and shrubs not included; state 2017), of which 450,985 ha are oak coppice forests and these are classified in 2 management classes (' $M$ ' and ' $L$ '). The remaining 98,282 ha are beech coppice forests. During the second half of the $20^{\text {th }}$ century, some coppice forests in North Macedonia were planned to be converted by direct and indirect means, while the others were planned to be managed as coppice forests with a rotation period up to 50 years (Long-term State Program), similarly to other European countries [5, 21, 24].
Hazelnut trees sprouts height (dep.4a)

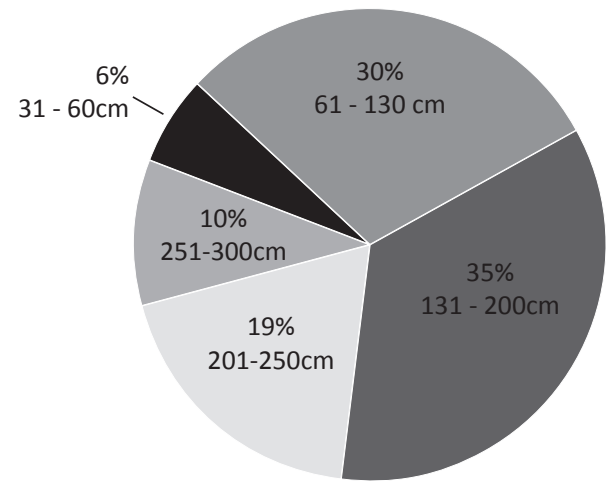

FIGURE 6. Height of hazel tree sprouts in department 4a

Indirect conversion was planned for a large proportion of coppice forest stands of oak and beech, i.e. a total of 150,000 ha. In the period of validity of the Program, in many stands, activities were accordingly implemented, i.e. one to two thinning operations have been performed. Presently, these stands should be at age of $70-90$ years and activities to finally transform them into high forests should be planned and performed, i.e. the provision of natural regeneration and the removal of the older stand. In planning the activities for final transformation, an important aspect is the capability of the stand for generative regeneration, i.e. seed production, as well as resprouting capacity of the stools. Low capacity for seed production of trees could pose a problem for successful regeneration, while high capability of resprouting impedes successful development of seedlings. On the other hand, low capacity for resprouting disables regeneration by vegetative means.

In QPCF stands in which clear-cutting has been performed we registered 24-28 thousand seedling individuals per hectare, while in QFCF 28-45 thousand seedling individuals per hectare. These data in particular suggest that for QPCF stands at ages of over 80 years activities could, and should, 
be planned for their final transformation into high forests by natural means. Our results suggest that, should the uniform shelterwood system be used for these stands, the regeneration of oak of generative origin would be of appropriate quality and quantity [7, 25].

Some trees of $Q$. petraea and $Q$. frainetto can produce shoots for up to 100 years or even indefinitely [23]. However, in QPCF and QFCF stands managed as simple coppice, from the aspect of resprouting potential the maximum rotation age should be 40 years [10]. On the other hand, investigations of the resprouting ability of $Q$. petraea stumps $80-100$ years after the last coppicing show low stool mortality and vigorous sprout growth after two vegetation years and demonstrate that old stumps can still regenerate well [24].

However, our research has shown that the production of sprouts at ages over 80 years is substantially decreased and that the number of resprouted stools is far from desired levels for restocking a site, which have been calculated in previous research [24]. Accordingly, it cannot be considered that at ages over 80 years coppice forests can be regenerated vegetatively.

Additionally, our results have revealed a large presence of other woody species (Corylus avelana, Fraxinus ornus), which present a realistic threat for both generative and vegetative regeneration of the stands. If, in these types of stands, measures for nursing and protection of the young plants are not applied, they will transform into hazel bushes, as was registered in the case of QPCF stands which were the subject of our research (Figure 7).

\section{CONCLUSIONS}

Finally, data derived from our research have shown that for the biggest part of oak coppice forests the coppice system is planned, i.e. the continuation of management as coppice forests. Further on, for both oak species the production of sprouts at ages over 80 years is substantially decreased. We have registered some resprouting, but in numbers far from desired levels for restocking a site. Thus, it cannot be considered that at ages over 80 years coppice forests can be regenerated vegetatively.

In the stands of both oak species, we recorded a sufficient number of generative individuals per hectare, which exposes the prospect for their transformation into high forests by natural means.

Large presence of other woody species (Corylus avelana, Fraxinus ornus) presents a realistic threat for both generative and vegetative regeneration of the stands. If, in these types of stands, measures for nursing and protection of the young plants are not applied, they will transform into bushes.

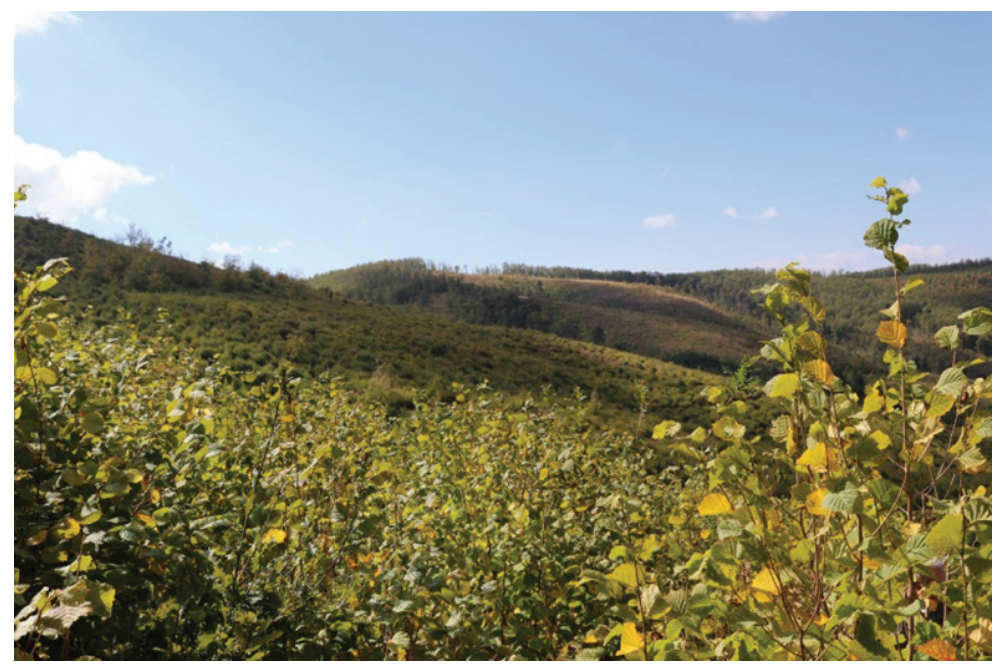

FIGURE 7. Department 4a (QPCF) four years after coppicing.

\section{REFERENCES}

1. UNRAU A, BECKER G, SPINELLI R, LAZDINA D, MAGAGNOTTI N, NICOLESCU V-N, BUCKLEY P, BARTLETT D, KOFMAN P 2018 Coppice Forests in Europe. University of Freiburg, Germany, $389 p$
2. CARVALHO J, MAGAGNOTTI N, NICOLESCU V-N, RUCH P, SPINELLI R, TOLOSANA E 2018 Active Management of Traditional Coppice Forests: An Interface Between Silviculture and Operations. In: Unrau A, Becker R, Spinelli R, Lazdina D, Magagnotti N, Nicolescu VN, Buckley P, Bartlett D, Kofman P (eds) Coppice Forests in Europe. Albert Ludwig University of Freiburg, Freiburg, Germany, pp 72-77 
3. CHATZIPHILIPPIDIS G, SPYROGLOU G 2004 Sustainable management of coppice forests in Greece. Towards the Sustainable Use of Europe's Forests-Forest Ecosystem and Landscape Research: Scientific Challenges and Opportunities, EFI Proceedings 49, pp 51-60

4. LEXER MJ, BOBINACM, DEKANIĆ S, DUBRAVACT, GEORGIEV G, GEORGIEVA M, HOCHBICHLER E, IVANOV G, JOVIC D, KASTNER E 2009 CForSEE: Multifunctional Management of Coppice Forests. Scientific results of the SEE-ERA.NET Pilot Joint Call. Centre for Social Innovation (ZSI), pp 49-56

5. STAJIC B, ZLATANOV T, VELICHKOV I, DUBRAVAC T, TRAJKOV P, LEXER M 2009 Past and recent coppice forest management in some regions of South Eastern Europe. Silva Balcanica 10 (1): 9-19

6. BARTLETT D, LAINA R, ZUPANIC M, GOMEZ MARTIN E 2018 The potential barriers to persistence and development of small scale coppice forest management in Europe. In: Unrau A, Becker R, Spinelli R, Lazdina D, Magagnotti N, Nicolescu VN, Buckley P, Bartlett D, Kofman P (eds) Coppice Forests in Europe. Albert Ludwig University of Freiburg, Freiburg, Germany, pp 166-175

7. KREJČI V, DUBRAVAC T 2004 From coppice wood to high forest of evergreen oak (Quercus ilex L.) by shelterwood cutting. Šumar List 128 (7-8): 405-412

8. KRSTIC M 2006 Silviculture. Transformation, reclamation and artificial regeneration. Faculty of Forestry, Belgrade, Serbia, $375 \mathrm{p}$

9. MATTHEWS JD 1991 Silvicultural systems. Oxford University Press, $284 p$

10. NICOLESCU V-N 2018 The Practice of Silviculture. Aldus, Brashov, Romania, $254 \mathrm{p}$

11. NIKOLOVSKI T 1957 The problem of conversion of forests in PR Macedonia. Journal of Forestry (5-6): 15-30

12. NIKOLOVSKI T 1955 Situation of bushes and guidance for their management. Forest Review 1: 3-44

13. NIKOLOVSKI T 1958 The forest vegetation types in Dub Mountain near Dojran Lake. Forest Review 5-6: 28-48

14. NIKOLOVSKI T 1960 The conversions problem of degraded hardwood forest in PR Macedonia. Forest review 5-6: 48-61

15. MIRCEVSKI S 1998 State and role on degraded forest vegetation in Macedonia, results from experimental plots, possibilities and direction for melioration. Melioration of degraded forest and shrubs Negorski Banji, Gevgelija, pp 12-24
16. GRUJOSKI B 1959 General development of the forestry in PR Macedonia (1944-1959). Forest Review Jubilee edition 7-27

17. MIRCEVSKI S 1977 Biostructural relations in lowtrunk wood of beech in Macedonia. Journal of Forestry 3-4: 12-26

18. NIKOLOVSKI T 1964 Low income forest in SFR Yugoslavia and possibilities for transformation into high income ones. Forest review 3-4: 3-15

19. POPOVSKI P 1979 Associable and economical value of the degrading forests and brushwood of S.R. Macedonia. Journal of Forestry 3-4: 13-19

20. TRAJKOV P, NESTOROVSKI L, TRAJANOV Z 2016 The Republic of Macedonia. In: Vidal C, Alberdi I, Hernández L, Redmond JJ (eds) National Forest Inventories. Springer International Publishing, Switzerland, pp 667-682. DOI: https://doi. org/10.1007/978-3-319-44015-6

21. BARTLETT D, LAINA R, PETROVIĆ N, SPERANDIO G, UNRAU A, ŽUPANIĆ M 2018 Socio-Economic Factors Influencing Coppice Management in Europe. In: Unrau A, Becker R, Spinelli R, Lazdina D, Magagnotti N, Nicolescu VN, Buckley P, Bartlett D, Kofman P (eds) Coppice Forests in Europe. Albert Ludwig University of Freiburg, Freiburg, Germany, pp 158-165

22. MIRCEVSKI S, VASILEVSKI K, VELKOVSKI N 2012 Amelioration of degraded forests and shrubs. "Ss. Cyril and Methodius" University, Faculty of Forestry, Skopje, North Macedonia, 211 $\mathrm{p}$

23. NICOLESCU V-N, CARVALHO J, HOCHBICHLER E, BRUCKMAN V, PIQUÉ-NICOLAU M, HERNEA C, VIANA H, ŠTOCHLOVÁ P, ERTEKIN M, TIJARDOVIC M 2018 Silvicultural guidelines for European coppice forests. In: Unrau A, Becker R, Spinelli R, Lazdina D, Magagnotti N, Nicolescu VN, Buckley P, Bartlett D, Kofman P (eds) Coppice Forests in Europe. Albert Ludwig University Freiburg, Freiburg, Germany, pp 46-63

24. PYTTEL PL, FISCHER UF, SUCHOMEL C, GÄRTNER SM, BAUHUS J 2013 The effect of harvesting on stump mortality and resprouting in aged oak coppice forests. Forest Ecol Manag 289: 18-27 https://doi.org/10.1016/i.foreco.2012.09.046:

25. DUBRAVAC T, TURK M, BARCIC D 2018 Konverzija panjača hrasta crnike (Quercus ilex L.) oplodnim sječama - rezultati višegodišnjih znanstvenih istraživanja. In: Šarić T, Beus V (eds) Poljoprivreda i šumarstvo na kršu mediteranskosubmediteranskog istočnojadranskog područja-stanje i perspektive, 5 June 2018, pp 103-121 